\title{
Kitle İletişim Araçlarının Hedonizm Ekseninde Günlük Yaşam İçerisindeki Kullanım Alanları
}

\section{Uses of Mass Media in Daily Life on the Axis of Hedonism}

\author{
Hacer Filiz ${ }^{\text {a,* }}$ \\ ${ }^{a}$ Dr. Öğr. Görevlisi, Pamukkale Üniversitesi, İletişim Fakültesi, Halkla İlişkiler ve Tanıtım Bölümü, 20160, Denizli/Türkiye. \\ ORCID: 0000-0001-5591-7092
}

\section{MAKALE BILLGISI}

Makale Geçmişi:

Başvuru tarihi: 03 Ocak 2020

Düzeltme tarihi: 25 Nisan 2020

Kabul tarihi: 04 Mayıs 2020

\section{Anahtar Kelimeler:}

Kitle İletişim Araçları

Hedonizm

Günlük Yașam
ÖZ

Kitle iletişim araçları bireylerin günlük yaşamını etkileyen ve belirli bir forma sokan olgulardır. Bireyin işe giderken arabasında açtığı radyo, evinde dinlenirken izlediği televizyon ya da her an çeșitli mobil araçlarla kullandığı internet ağları bireyin günlük yaşamını çepeçevre sarmaktadır. Söz konusu etkiler sayesinde kişi içinde yaşadığı toplumda var olan siyasal ya da bireyin ekonomik karar alma süreçlerine tesir eden mesajlara maruz kalabilir. Siyasal ve ekonomik tercihleri kontrol altında tutmak amacıyla hazırlanan bu mesajların en önemli ileticisi ve taşıyıcısı ise kitle iletişim araçlarıdır. $\mathrm{Bu}$ perspektiften bakıldığından bu çalışmada kitle iletişim araçlarının bireyin günlük yaşam düzeni içerisinde hangi amaçlarla kullanıldığ 1 ve kișinin hedonizm odaklı olușturduğu ekonomik ve siyasal tercihleri nasıl gerçekleştirdiği kitle iletişim araçları ve hedonizmin kısa bir tarihçesinden bahsedilerek açıklanmaya çalışılmıştır.

\section{ARTICLE INFO}

\section{Article history:}

Received 03 Januray 2020

Received in revised form 25 April 2020

Accepted 04 May 2020

\section{Keywords:}

Mass Media

Hedonism

Daily Life

\begin{abstract}
A B S T R A C T
Mass media are phenomena that affect the daily life of individuals and put them in a certain form. The radio that the individual opens in his car while he is going to work, the television he watches while he is resting at home, or the internet networks he uses with various mobile devices at any time surround the daily life of the individual. Thanks to these effects, the individual may be exposed to messages that affect the political or economic decision-making processes of the individual in the society he / she lives in. The most important transmitter and carrier of these messages, which are prepared to keep political and economic preferences under control, are the mass media. From this perspective, this study attempts to explain the purposes for which the mass media are used in the daily life of the individual and how the individual makes economic and political choices focused on hedonism by mentioning a brief history of mass media and hedonism.
\end{abstract}

\section{Giris}

İletişim, bireyin hayatını devam ettirebilmesi için gerçekleştirilmesi gerekli bir sosyal faaliyet ve ilişskidir. Bu pencereden bakacak olursak hem bireyin toplum içindeki ilişkilerini devam ettirmek adına kurduğu toplumsal iletişim hem de bireysel olarak hem cinsleriyle kurduğu kişilerarası iletişim ve bu iletişim türlerinin kurulmasına aracılık eden çeşitli iletişim araçlarının birey açısından hayati bir öneme sahip olması artık günümüzde herkesin üzerinde fikir birliğine vardığı yadsınamaz bir gerçektir.
Her bir kitle iletişim aracı hedef kitlesiyle bir araya gelmektedir ve insanlar üzerinde önemli derecelerde etkilere sahip olan bu kitle iletişim araçları sahip oldukları içerikleri hedef kitlelerine ulaştırarak onlara bu içeriklerde saklı olan mesajları da iletmektedirler (Erdem, 2014: 64).

Gündelik yaşamın artık vazgeçilmez bir parçası haline gelen kitle iletişim araçları birçok anlamda kitleleri etkilemektedirler. Örneğin televizyon siyasi karar alma aşamasın da seçmenin kararlarını etkilemektedir. Hatta seçimlerde bir adaya oy verme söz konusu olduğunda bireyin tercihinde kitle iletişim araçlarının sosyal ve psikolojik faktörlerle birlikte önemli sayılacak derecede etkisi olduğu

\footnotetext{
* Sorumlu yazar/Corresponding author.

e-posta: hfiliz@pau.edu.tr
} 
söylenebilir (Kaypakoğlu, 2004: 95). Ya da Youtube, Twitter, İnstagram gibi çeşitli sosyal medya araçları okullarda evde ya da iş yerlerinde bireylerin eğitim, bilgilendirilme ya da günümüzde en çok kullanıldığı hali eğlence amaçlı olarak kullanımına olanak sağlamaktadır.

Özellikle Amerika menşeili yapılan birçok araştırmaya göre günlük yaşamda bireylerin zamanlarının neredeyse yarısından çoğu kitle iletişim araçlarını kullanarak ya da bu araçların etkilerine maruz kalarak geçmektedir. Bu oran insanların uyumak için sarf ettikleri zaman diliminden daha fazladır. Kimi kitle iletişim araçları ise bireylere her gün finansal, sosyal ve kültürel açıdan etkide bulunmaktadır. Hatta kitle iletişim araçları oy verme biçiminizi, ekonomik olarak yaptığınız harcama biçimlerinizi bile şekillendirebilir. Aynı zamanda çoğunlukla kitle iletişim araçları beslenme, konuşma, çalışma ya da dinlenme biçiminizi de şekillendirebiliyor (Biagi, 2007: 4).

Toplumu denetim altında tutmak maksadıyla ideolojik bir denetim sistemi, toplumda var olan güç yapısının tahsis edilmesi ve maddi bir denetim sağlama ve toplumda hakimiyetini sürdürmekte olan egemen çıkar grupların bu teknolojik yeniliklerle desteklendiği söylenebilir (Turan ve Esenoğlu, 2006: 71). Bu teknolojik yeniliklerin toplum üzerinde en etkili olan araçları ise kitle iletişim araçlarıdır. Kitle iletişim araçları günlük yaşam içerisinde özellikle bireyin siyasal ve ekonomik anlamda verdiği kararları ve tercihleri etkilemektedir.

Egemen gruplar ya da kişiler tarafından bireylerin ve büyük pencereden bakıldığında toplumların özellikle hedonizm ekseninde yani duygusal anlamda kontrol altında tutulmasına kitle iletişim araçları yardımcı olmaktadır. Hedonizm tarihin değişik dönemlerinde birçok farklı filozof tarafından ele alınan felsefi bir kavram ve düşüncedir. İlk olarak Antik Yunan filozofları tarafından ele alınan bu felsefi kavram kişinin erdemli bir birey olabilmesi için acıdan uzaklaşıp hazza yaklaşmasını gerekli bir durum olarak görmekteydiler.

Antik Yunan filozoflarının acıdan uzaklaşıp bireyin kendini mutlu eden ve hazza yaklaştıran durum ve olgulara yönelmesi olarak tanımladıkları hedonizm, günümüz toplumlarında varlığını sürdüren bireyler tarafindan benimsenen bir hayat görüşü durumuna gelmiştir. Toplum içerisinde var olan siyasal ve ekonomik güç odakları kitle iletişim araçlarını kullanarak bireyin tercihlerini ve seçimlerini etkilemektedir. Bu söz konusu ekonomik ve siyasal kişi ve grupların bireyi etkileme metotları çok çeşitli şekillerde gerçekleşiyor olsa da yapılan araştırmalar göstermektedir ki bu etki şeklinin büyük bir bölümü duygusal platformda özellikle hedonizm ekseninde gerçekleşmektedir.

Bireyin kendini mutlu eden şeylere yönelmesi ve huzursuzluk duyacağı durum ve nesnelerden uzak durması günlük hayatta kişinin uyguladığı bir stratejidir. İşte tam da bu noktada ekonomik ve siyasal anlamda söz hakkı olan kişiler kitle iletişim araçlarını kullanarak bireyi duygusal açıdan etkileyerek kontrol altında tutmak istemektedirler. Bireyin günlük yaşam içerisinde ve hedonizm ekseninde kitle iletişim araçları yoluyla etki altında bırakılması ve bu etkinin bireyin siyasi ve ekonomik karar alma süreçlerine tesir etmesi çalışmamızın temelini oluşturmaktadır.

\section{2. İletişim ve Kitle İletişimi}

İletişim diğer insanlarla konuşmaktır, aynı zamanda iletişim televizyon, gazete gibi kitle iletişim araçlarıdır, ya da iletişim saç şeklimiz, giyinme tarzımızdır (Zıllıoğlu, 2014: 21). Hatta zaman zaman kullandığınız bir parfüm ya da giydiğiniz ayakkabı bile başka kişilerle iletişim kurma biçimi olabilir.

İletişim insanların bir araya gelerek aynı zaman ve mekânı paylaşarak yüz yüze yaptıkları bir müzakere bir konuşmadır, aynı zamanda iletişim kitle iletişim araçlarından paylaşılan bilgilerdir ya da iletişim bir insanın saçını toplama ya da sacını kestirme şeklidir ya da iletişim yazınsal bir eleştiridir (Fiske, 2011: 71).

İletişimin boyutu tarihi süreç içerisinde hem bireylerin birbiriyle hem de büyük toplulukların birbirleriyle iletişiminde değişimler göstermiş̧tir. Sanayileşme ve kent kültürünün hâkim olmaya başlamasından önce geleneksel sosyal yapılanmalarının olduğu toplumlarda genellikle daha samimi olarak görülen yüz yüze iletişim, kişilerarası ve grup iletişimi hakimdi. Fakat sanayileşmenin gerçekleşmesiyle birlikte köyden kente göçlerin meydana gelmesi ve beraberinde geleneksel bir aile yapilanmasından modern toplum ve bunun yansiması olarak modern aile yapılanmalarının sosyal hayat içerisinde hüküm sürmesi önce kitlesel iletişimi ön plana çıkarmış daha sonrada günlük yaşam içerisinde kitle iletişim araçlarının sıç̧a kullanılmasına sebebiyet vermiştir. Çünkü artık geleneksellikten büyük oranda sıyrılmış olan modern birey çevresinde ve hatta dünyada olup biten olayları merak eder duruma gelmiştir.

Aysel Aziz (2016: 125) kitlesel iletişimi ve kitle iletişim araçları ilişkisini şu şekilde açıklamaktadır "Kitlesel iletişim ve onun aracı niteliğinde olan kitle iletişim araçları, sözcüklerin çıplak anlamları ile açıklanacak olursa, iletişimin, kitleler arasında, kitle iletişim araçlarının kullanılarak yapıldığı bir iletişim türü ya da tipidir."

Kitle iletişimi; kitle iletişim araçları vasıtasıyla farklı özelliklere sahip bireylerden oluşan kitlelerle kurulan tek taraflı olarak gerçekleştirilen bir iletişimdir türüdür. En yaygın olarak kullanılan kitle iletişim araçları; televizyon başta olmak üzere, radyo, sinema, gazete, dergi ve günümüzde etki alanı tahmin edilemeyen boyutlara ulaşan sosyal medyadir.

Toplumsallaşma sürecinde önemli bir yere sahip olan kitle iletişim araçları, özellikle televizyon, kitleleri yönlendirmekte ve etkilemekte önemli bir güç unsuru olmuştur. Kitle iletişim araçları yaptıkları yayınlar yoluyla bireylerin duygu, düşünce ve en nihayetinde davranışlarına tahmin edildiğinden çok daha fazla bir biçimde etki etmektedir. Bu etkiyi televizyon dizisinde ölen bir karakterin (kurtlar vadisi-çakır karakteri) gerçek hayatta insanlar tarafından cenaze namazının sanki gerçekten ölen birisi varmışçasına üzüntüyle kılınması bize açıkça göstermektedir.

\section{Kitle İletişim Araçlarının Kısa Bir Tarihçesi}

İletişim doğal araçlarla örneğin sözlü ya da insan hareketleri jest ve mimikleriyle oluşturulabildiği gibi çoğu zaman insan eliyle oluşturulmuş ve teknolojinin de yardımıyla her geçen gün gelişme gösteren aynı zamanda da toplumlar üzerinde büyük etkiye sahip olan televizyon, radyo, gazete, internet 
gibi kitle iletişim araçları vasıtasıyla da gerçekleştirilebilir (Çakır ve Topçu, 2005: 72).

Teknolojinin gelişmesine bağlı olarak gelişme ve değişme gösteren kitle iletişim araçları küreselleşmenin de etkisiyle farklı bölgelerdeki hatta farklı kıtalarda meydana gelen hadiseleri zaman ve mekân kavramını aradan çıkararak anında insanlara sunmaktadır. Hatta bireyler dünya üzerinde gerçekleşen bu önemli olaylara koltuklarından hiç kalkmadan yani habere ulaşmak için herhangi bir çaba sarf etmeden sahip olabilmektedirler. Bu durumun çoğu zaman olumsuz yansımaları olsa da kimi zaman olumlu geri dönüşleri de yaşanmaktadır.

Dünya üzerindeki bir ülkenin başına gelen doğal bir doğa felaketi ya da bir terör saldırısı sonucu ülkede meydana gelen tahribatlar kitle iletişim araçları sayesinde an itibariyle tüm ülkelere sergilenebiliyor ve bu felaketlerin duyurusu anında yapılabiliyor. $\mathrm{Bu}$ felaketlerden haberi olan ülkeler daha olayların üzerinden 24 saat geçmeden bu gibi ülkelere yardımda bulunup kültürel hatta dini açıdan kendilerinden tamamen farklı olan bu insanlara yardım edebiliyorlar ve dayanışma içinde olabiliyorlar. Bu durumu ortaya çıkaran ve duyurusunu yapan kitle iletişim araçlarının ise bu anlamda çok işlevsel olabildiği herkes tarafından kabul görmektedir.

Kitle iletişimi radyo, sinema, televizyon, gazete, dergi ve diğer basılı yayınlar, sosyal medya aracılığıyla meydana getirilen iletişim şeklinde sıralanabilir ve kitle iletişimi 1800'lü yılların son döneminde tarih sahnesine çıkmış ve sosyal anlamda üretimin bel kemiği haline gelmiştir (Yaylagül, 2016: 15).

Kitle iletişim araçlarının ortaya çıkışması ve gelişim süreleri birbirinden farklı seyirler izlemiştir. Genel olarak kitle iletişim araçlarını sıralayacak olursak bu sıralamaya gazeteyle başlayabiliriz. Sinema diğer bir kitle iletişim aracıdır. Daha sonra işitsel bir kitle iletişim aracı olan radyodan bahsedebiliriz. Televizyon ise icadiyla beraber büyük kitleleri etkileme ve yönlendirme işleviyle karşımıza çıkmaktadır. Günümüzde ise televizyonla birlikte kitleleri en çok etkileyen hem kişilerarası iletişim hem de bir kitle iletişim aracı olarak kullanılan internetten bahsedebiliriz. Yukarıda saydığımı bu kitle iletişim araçları kitleler tarafindan en yaygın olarak kullanılan kitle iletişim araçlarıdır.

Tarih serüveni içerisinde her yeni ortaya çıkan kitle iletişim aracı bir diğerinin etki alanını azaltmıştır. Önce görsel sonra işitsel daha sonra hem görsel hem işitsel ve günümüzde ise görselliğin ve işitselliğin ötesinde aynı zamanda kitle iletişiminde interaktif bir iletişim olanağına imkân veren kitle iletişim araçları kitlelerle buluşmuştur. İletişim teknolojilerindeki gelişime bağlı olarak kitle iletişim araçlarında meydana gelen bu yenilikler kaynak ve alıcı arasındaki iletişimin boyutlarını tahmin edilemez noktalara taşımıştır.

Matbaanın 1440 yilında icat edilmesine değin M.S. 7. yüzyılda Çin'de düzenli aralıklarla çeşitli yayınlar çıkartılmış olsa da modern basın serüveni matbaanın bulunmasıyla beraber başlamıştır ve düzenli ilk yayınlar 1631'de Fransa'da Hükümetin resmi olarak La Gazette yayınını çıkartmasıyla başlamıştır (Kaypakoğlu, 2004: 39).

Matbaanın icadıyla beraber ilk olarak kitaplar basılmaya başlanmış ve yazarlar seslerini kitlelere kitaplar sayesinde duyurabilme imkanına kavuşmuşlardır. Daha sonra 17. yüzyılın başlarında gazeteler tarih sahnesine çıkmışlardır. Gazete, okuyucu kitlesi çok geniş olan çok geniş ölçekli ve çeşitli bilgiler sunan ve genel anlamda günlük olarak okuyucu kitlesine hizmet veren süreli bir kitle iletişim aracidir.

Gazete Türk Dil Kurumunun güncel Türkçe sözlüğünde (2006) "Politika, ekonomi, kültür ve daha başka konularda haber ve bilgi vermek için yorumlu veya yorumsuz, her gün veya belirli zaman aralıklarıyla çıkarılan yayın" şeklinde tanımlanmaktadır.

Gazete, enformasyonların toplanarak bireylere ulaştırılması ve bu şekilde toplum içerisinde bir kamuoyu oluşturarak bir iletişim süreci gerçekleştiren ve icat edildiği günden buyana bireyler üzerinde en etkili kitle iletişim araçlarından bir tanesidir. Gazete radyo ve televizyondan farklı olarak sadece göze hitap eden bir kitle iletişim aracıdır ve bireyin bu kitle iletişim aracından faydalanması için gazetenin yazıldığı dile hâkim olması gerekir yani birey gazeteyi okumak için belli bir seviyede okur yazarlık seviyesine sahip olmalıdır.

Gazete toplum içinde okunmaya başladığı dönemden günümüze tren, otobüs gibi yolculuklarda bireyin içtiği bir bardak kahve ya da çayına arkadaşlık eden ve bireyin serbest zamanlarını değerlendiren bir araç olarak kullanılagelmiştir (Williams, 2010: 1).

Diğer bir kitle iletişim aracı ise dergidir. Dergi süreli yani belirli periyotlarla hedef kitlesine hizmet veren bir kitle iletişim aracıdır. Gazeteden farklı olarak derginin sahip olduğu en önemli özellik dergilerin spesifik alanlara ayrılması. Yani dergiler gazetelere oranla daha çok genele değil özele, insanların ilgi duyacağı alanlara ayrılırlar. Örneğin çocuk dergileri, bilim dergileri, ekonomi dergileri, moda dergileri, dekorasyon dergileri, meslek dergileri vs. gibi birçok farklı dalda dergiler çıkartılır. Bu farklılıklar içerisinden bireyler kendi ilgi alanlarına uygun olan dergiyi seçip okurlar. Fakat bu dergiler gazete gibi her gün değil belirli zaman aralıklarında okuyucusuyla buluşur.

Günümüzde dergiler giyinme biçimimizden, yemek pişirme, çocuk bakımı, hangi ürünleri satın almamız gerektiği, ya da zamanımızı ne şekilde planlamamız gerektiği ve geleceğe dair takvim oluştururken nelere dikkat etmemiz gerektiğini bize söylemektedirler. Ayrıca dergiler artık sadece basılı olarak değil elektronik olarak da evlerimizde ya da iş yerlerimizde bizim dikkatimizi çekerek bizi yönlendirmeye çaba sarf etmektedirler (Walker, 1998: 1).

Gazete ve dergilerden sonra tarih sahnesine çıkmış olan sinema belirli sayıdaki fotoğrafların bir araya getirilerek görüntüye hareket kazandırılması esasına dayanan görüntülü bir kitle iletişim aracıdır. İlk ortaya çıktı̆̆ı dönemlerde izleyicisine sadece görüntülü birtakım sahneler sunan sinema daha sonra teknolojinin gelişme göstermesi ve bu durumun sinema teknolojilerine de yansımasiyla beraber görüntüye ses de eklenmiş ve böylece sinema hem göze hem de kulağa hitap eden bir kitle iletişim aracı haline gelmiştir.

1877 yılında Edison tarafından ilk defa ses makinasının kullanılması ve daha sonra Lumiere Kardeşlerin ilk film gösterimini 1895 yılında gerçekleştirmeleriyle birlikte sinema endüstrisi çok hızlı bir şekilde uluslararası bir boyut kazanmaya başlamıştır (Mattelart, 2016: 43). 
19. yüzyılda ilk sinema örnekleri karşımıza çıkmaktadır. Sinema ilettiği mesajlarla kitleleri etkileyen önemli bir kitle iletişim aracıdır. Özellikle 20.yy'ın ikinci yarısından sonra sinemanın kitleler üzerindeki yönlendirici etkisi daha iyi anlaşılmış ve Avrupa'daki çeşitli ülkeler tarafından kitleleri kendi amaçları doğrultusunda yönlendirmek için sinema önemli bir propaganda aracı olarak görülmüş ve bu amaçla kullanılmıştır.

1900'lü senelerin ilk yıllarında sinema hakkında bir takım hararetli tartışmalar baş göstermiştir. Çok fazla sayıdaki kanaat önderleri, sinema filmlerinin mazinin insanlara bırakmış olduğu mirası yok edeceğini, heba edeceğini öngördüğü için sinema ürünlerine iyi gözle bakmamışlardır ve ayrıca daha sonraki yıllarda özellikle televizyon başta olmak üzere birçok kitle iletişim araçlarının da kaderi sinemanınkiyle aynı olmuştur (Sorlin, 1997: s.4).

Sinemanın ardından radyo yayınlarının yapılması adına ilk çalışmalar 1860'lı yıllarda Avrupalı bilim adamları tarafından yapılmaya başlanmış olsa da radyo telsizinin ilk yayınını yapması 1920'li yıllara uzanmaktadır (Aziz, 2013 :37). Radyo sinemadan sonra insanların hayatına giren önemli bir kitle iletişim aracıdır. Radyonun kullanılmaya başlanmasından kısa bir süre sonra tıpkı diğer önemli kitle iletişim aracı olan sinema gibi kitleler üzerindeki etkisi anlaşılmış ve önce I. Dünya savaşı yıllarında sonra II. Dünya savaşı yıllarında yoğun bir şekilde hedef kitleleri etkilemek için bir propaganda aracı olarak kullanılmıştır. Fakat 20. yüzyılın ikinci yarısından itibaren diğer bir kitle iletişim aracı olan televizyonun insanların hayatına girmesiyle birlikte kitlelerin gözünde radyo artık eski popülerliğini yitirmiştir. Çünkü radyoyu tahtından indiren televizyon ses ve görüntüyü birleştirmiş hem kulağa hem de göze hitap etmeye başlamıştır.

Hem göze hem kulağa hitap eden bir kitle iletişim aracı olan televizyonun tarih sahnesine çıkmasıyla birlikte radyo prime time'daki yerini her ne kadar televizyona devretmiş olsa da bireylerin prime time dışındaki zamanlarını doldurmayı başarabilmiştir. Radyo mutfakta, yatak odasında, banyolarda, iş yerlerinde ve üretim alanlarında ya da bireyler gezerken kişiye geri plandan şarkılar söylemeye, bireyi eğlendirmeye ya da bireyi bilgilendirmeye devam etmekte ve kişinin hayatındaki önemli yerini büyük oranda muhafaza etmektedir (Himes ve Lovinglio, 2002: 1).

Televizyon, hareketli görüntüleri elektromanyetik dalgalara dönüştürerek uzaklara ileten ve bu dalgalardan, yeniden görüntü elde ederek çalışan bir sistemdir. Televizyonun icadına kadar saydığımız bütün kitle iletişim araçları televizyonun icat edilip geliştirilmesinde birer mihenk taşı olmuşlardır. Televizyon icat edilip kitlerle buluştuktan sonra diğer tüm kitle iletişim araçlarını tahtından etmiştir. Artık sesin yanında bir de hareketli görüntüleri izleyebilen bireyler televizyonun büyülü dünyasına istekli bir şekilde giriş yapmışlardır.

Televizyon kendinden önceki teknolojilerin bilgi birikimiyle birlikte ortaya çıkarılan bir teknolojik yeniliktir. 1875 ve 1890 yılları arasında diğer teknolojik aygıtlardan yavaş yavaş ayrılmaya başlasa da televizyonun tarih sahnesine henüz bir kamusal hizmet olarak girmesi 1920'den 1930'lar olarak söylenebilir. Televizyonun saydığımız bu aşamalardan geçmesi ise yine kendisinden önce var olan teknolojik aygıtların bilgi birikimidir. İlk olarak elektrik düzeneğinin bulunması daha sonra sırasıyla telgraf, fotoğrafçılık, hareketli görüntülerin geliştirilmesi ve radyo konusundaki birtakım icatlar televizyon teknolojisinin nasıl geliştirilip ortaya konulduğunu insanlığa açıklamaktadır (Williams, 2004: 7).

Televizyonun kendine has en önemli özelliği ucuz, erişimi kolay ve isteyen tüm bireylerin zahmetsiz bir şekilde bir ayrıma ve şarta tabi tutulmaksızın televizyon yayınına ulaşabilmesidir. Televizyonun kendisinden önce faaliyet gösteren tüm kitle iletişim araçlarından farklı kılan özelliği şudur ki; izleyici profili açısından toplum içinde bir ayrım gözetmemektedir.

Televizyon icat edildiği dönemden günümüze kadar neredeyse popülerliği hiç azalmayan bir kitle iletişim aracı olmuştur. İnsanların kolay ve ucuz şekilde televizyon yayınlarına erişebilmesi televizyonu kitleler üzerinde etkili bir kitle iletişim aracı haline dönüştürmüştür. Televizyon yayınlarının içerikleri çok geniş bir boyutta izleyicisine hizmet sunmaktadır; eğitim, eğlence, bilgilendirme vs. birçok alan televizyonun içeriğini oluşturmaktadır. Böylece televizyon her seferinde çok farklı istek ve beklentileri olan hedef kitleyi kendine çekmeyi başarmaktadır.

Günümüzde televizyon programlarının içeriklerinde eğlence formatlı yapımlar izleyiciyle sıklıkla buluşturulmaktadır. Postman'1n görüşüne göre ise (2014: 102), televizyon programlarında eğlence en üst noktada izleyicilere sunulur, neredeyse yayınlanan tüm televizyon programlarının amacı toplumu bilgilendirmek, bireyde bir arınma rahatlama meydana getirmek ya da herhangi bir eğitim işlevi yerine getirmek değildir, televizyon programlarının amacı tüm televizyon formatlarını bir eğlence söylemiyle izleyiciye iletmektir.

Yaşadığımız dönem içerisinde var olan yeni iletişim teknolojileri televizyonun sarsılmaz egemenlik alanını biraz daraltmış olsa da televizyon hala birey ve toplum üzerinde fazlasıyla söz sahibi olan etkili bir kitle iletişim aracıdır. Özellikle Youtube, Twitter, İnstagram gibi sosyal medya ürünlerinden sonra en çok kullanılan kitle iletişim aracı, popülerliğini neredeyse hiç kaybetmeyen görüntünün ve sesin birleşiminden ortaya çıkan büyülü dünyaya insanları sürekli davet eden televizyondur.

Yaşanılan dönem içerisinde artık internetsiz bir hayat düşünülemez hale gelmiştir. İnternet hem insan hayatını kolaylaştıran bir araç hem de bireylerin günlük hayatında hem özel hem iş ortamlarında zorunlu bir ihtiyaç haline gelmiştir. O nedenle önemli bir kitle iletişim aracı olarak karşımıza çıkan internet vasıtasıyla kurulan kitle iletişimi kişiler tarafından en çok tercih edilen iletişim biçiminden biridir.

İnternet teknolojisi Tim Berners-Lee tarafindan 1991 yılında Hypertext (http) teknolojisinin bulunması ve internetle bağlantısını sağlamak için World Wide Web'in icat edilmesi ile ortaya çıkan yeni bir tür ağ iletişimidir. (Van Dijck, 2013: 5).

Diğer birçok kitle iletişim aracında görüldüğü gibi internet de ilk olarak askeri amaçla icat edilmiş fakat daha sonra geliştirilerek toplumun kullanımına da açık hale getirilmiştir. Türkiye'de internetin kullanımı 1990'lı y1lların son zamanlarına rastlamaktadır (Anıl ve Köksal, 2016: 3) İlk kullanılmaya başlandığı zamandan günümüze çok fazla 
gelişme gösteren yeni medya günümüzde kontrol altında tutulması çok zor ve kitleler üzerindeki etkisi öngörülemeyecek derecede fazla olan bir kitle iletişim aracidir.

Time Berners-Lee'nin veri alış-verişi amacıyla icat ettiği internet günümüzde çok farklı amaçlara hizmet etmektedir. İnternet aracılığıyla oluşturulan sosyal medya ağları günümüzde kitleleri etkileme gücü tahmin edilemeyecek boyutlara ulaşan bir iletişim aracıdır. Sosyal medya diğer bir ismiyle yeni medya iletişim teknolojilerindeki meydana gelen gelişimin bir ürünüdür. Sosyal medyanın bir diğer adı yeni medyadır çünkü yeni medya önceki var olan diğer kitle iletişim araçlarından çok farklıdır. Örneğin televizyon ya da diğer kitle iletişim araçlarında hedef kitleler pasiftir. Kitle iletişim aracını kullanarak genellikle herhangi bir etkileşimde bulunmazlar. Kendilerine kitle iletişim aracından gelen mesajları alırlar ve çoğu zamanda bu mesaj doğrultusunda davranış ya da tutum değişikliğine gidebilirler. Fakat yeni medyada hedef kitle artık pasif değildir. $\mathrm{Bu}$ anlamda iletişim artık farklı boyutta yaşanmaktadır.

Bireyler yeni medya mecralarında karşısındaki kişilerle sürekli etkileşim içindedirler yani zaman ve mekân algısı artık farklı boyutuyla yaşanmaktadır sosyal medyada. Aynı zamanda eskiden kişilerin kitle iletişim araçlarının içeriğine müdahale etme, bu içeriği değiştirme ya da yeniden oluşturma gibi bir seçenekleri yoktu. Fakat yeni bir kitle iletişim aracı olan internetin kitlelerin hayatına girmesiyle beraber artık bireyler sosyal medyadaki programların içeriğini de kendileri oluşturabiliyorlar ya da var olan bir içeriğe müdahale ederek değiştirebiliyorlar. Örneğin televizyonda bu işe sadece yayın editörleri ve diğer üst düzey yöneticiler karar verir ve oluştururdu. Fakat yeni medyada bu durum tamamen değişmiştir.

Şimdiye kadar bahsettiğimiz kitle iletişim araçları dışında başka kitle iletişim araçları da mevcuttur. Örneğin; siyasi bir ses duyurma aracı olan genellikle ülkede yapılacak olan seçimler öncesinde seçmen kitlesine sesini duyurmak ve onların karar alma süreçlerine etki etmek amacıyla düzenlenen mitingler birer kitle iletişim aracıdır.

Genellikle ticari kaygılarla hazırlanan reklam afişlerinin billboardlarda yayınlanması da kitle iletişiminin bir örneğidir. Bilgilendirme amacıyla hedef kitlelere ulaştırılan el ilanları ya da broşürler de kitleleri bilgilendiren birer kitle iletişim araçlarıdır.

Kitle iletişim araçlarının tarihi seyri içerisinde, söz konusu bu araçların birey ve toplum üzerinde yaptıkları etki neticesinde çeşitli kuramlar geliştirilmiştir.

Kitle iletişimi adına yapılan çalışmalar sonucunda ortaya konulan kuramlar üç temel dönem üzerinde yoğunlaşmaktadır; bunlardan ilki kitle iletişim araçlarının toplum üzerindeki kuvvetli tesirler yaptığı periyotlar, ikincisi kitle iletişim araçlarının toplum üzerindeki sınırlı tesirler yaptığı dönem, son olarak ise medyanın kuvvetli tesirlerinin tekrar oluştuğu ve bu etkilerin araştırıldığ dönemdir. Kitle iletişim araçlarının birey ve toplum üzerinde kuvvetli tesirlerinin olduğu zamanlar 20. Yüzyılın başlarından ortalarına kadar devam eden bir dönemi kapsamaktadır. Bu dönemde yapılan çalışmalar sonucunda ortaya konulan analizler kitle iletişim araçlarından bireylere gönderilen iletilerin bireyde bir mermi kadar güçlü bir etki oluşturduğu yönündeydi. Kitle iletişim araçlarının birey üzerinde sınırlı etkiler bıraktığı dönemler ise 1940 ve 1960 yılları arasında meydana gelmiştir. $\mathrm{Bu}$ dönemde yapılan iletişim araştırmalarının sonuçlarında görülmüştür ki kitle iletişim araçlarının bireyler üzerindeki etkisi tutum ve davranışları değiştirme üzerinde doğrudan bir tesirde bulunamayacağı bunun yerine kültürel değerler ve inanç sistemleri birey ve toplum üzerinde daha etkili olduğu düşüncesi ortaya konulmuştur. 1960 sonrası yapılan iletişim araştırmaları ise kitle iletişim araçlarının birey ve toplum üzerinde ne denli önemli tesir gücü bulunduğunu bir kez daha ortaya koymuştur (Iş1k, 2012: 28-31).

\section{Kitle İletişim Araçları ve Hedonizm}

Günlük yaşam içerisinde kitle iletişim araçları vasıtasıyla hazzın ön plana çıkartılması yani bireylerin günlük yaşamdaki tercihlerini yaparken kendilerini mutlu edecek hedonik tercihlerde bulunmaları günümüz toplumlarında sıkça karşılaşılan ve hem sosyolojik hem de psikolojik açıdan incelenen bir durumdur.

Hedonizm düşüncesi tarihin farklı zamanlarında farklı kişiler tarafından değerlendirmeye tabi olmuş olsa da bu düşünceyi ilk defa irdeleyen kişiler antik Yunan filozofları olmuştur: ilk olarak Sokrates'in öğrencileri tarafindan değerlendirilen hedonizm sirasıyla önce Aristippos ve daha sonra Epikuros ile incelenmeye devam edilmiştir (Kaya Deniz, 2019: 103). Aristippos hedonik yaklaşımını bir temele yerleştirmeye çalışırken onun için asıl önemli olan şey acıdan kaçınırken hazza yaklaşmak olmuştur. Ona göre mutlu bir birey olmanın şartı buydu.

Epikuros ise hedonizmi acıdan kaçınmak ve insanın kendisini mutlu edene yaklaşması yani hazza yaklaşması olarak tanımlar. Epikuras'a göre yer yüzündeki her şeyde olduğu gibi hazzın da derecesinin bir sınırı vardır. Eğer hazzın bir ölçüsü olmaz ise kontrol altında tutulamayan bu sınırsız haz insana acı getirebilir (Öztürk Fidan, 2017: 601).

Aristippos'un kurmuş olduğu Kirene Okulu ise hedonizmi ortaya ilk olarak çıkartan okul olarak tanınmaktadırlar ve Kyreneciler hayatın merkezine hazzı koyarlar, hazzın var olmadığı yerde mutsuz aynı zamanda yaşamaya değer bir hayatın olmadığını savunurlar (Güven, 2019: 145).

Kirene okulunun temsilcileri hazzı aramanın bireyleri mutluğa götüren tek yol olduğunu savunurlar. Onlara göre bir nesne ya da bir olay, olgu kişiyi hazza ulaştırıyorsa yani kişiyi mutlu ediyorsa bahsi geçen olgu olumlu pozitif olarak anlam bulur. Fakat söz konusu olgu bireyi mutlu etmiyorsa onu hazza ulaştırmıyorsa negatif bir anlam taşır birey gözünde.

Hedonizmi reddeden iki filozof ise Sokrates ve Platondur. İyinin ve doğru bilginin kaynağının haz, istek ve arzuların olamayacağını 1srarlı bir şekilde dile getirmektedirler. Aristoteles ise hedonizme Sokrates ve Platonun düşünceleri kadar sert bakmamaktadır. Hedonik arayışın mutlu ve erdemli bir yaşam şekliyle bağlantısına dikkat çekmektedir.

Antik Yunandan günümüze geldiğimizde ise bireylerin aynı o dönemde olduğu gibi mutluluğa erişebilmek için hazcı tercihlerde bulunduğunu söyleyebiliriz. Günlük hayat içerisinde bireyin yaptığı tüketim tercihleri sadece fiziksel ihtiyaca değil aynı zamanda duygusal bir ihtiyacı karşılamaya yönelik de yapılmaktadır. Örneğin bireyin satın 
aldığı bir kazak onun örtünmesine ve 1sınmasına katkı sağladığı gibi kişiye hissettirdiği duygular anlamında da önemli olmaktadır.

Hirschman ve Holbrook (1982: 92) 'a göre Hedonik tüketim, kişinin ürünlerle olan ilişkisinin yani tecrübesinin duyusal ve duygusal olarak yönünü belirler ve ürün tüketici ilişkisine yön vermeye çalışır, yani tüketici davranışına duygusal ve duyusal anlamda yön verir.

Hedonik ve faydacı alışveriş üzerine yapılan araştırma sonuçları da göstermektedir ki hedonik ve faydacı alış veriş̧ ile yapılan alış veriş arasında anlamlı bir ilişki bulunmaktadır; araştırma sonucundan elde edilen verilere göre memnuniyet yani tüketicinin yapmış olduğu alış veriş sonrası yaşadığı mutluluk ve bunun sonucunda oluşan sadakat duygusu ve ağızdan ağıza iletişimle yayılan ürün memnuniyeti gibi bileşenlerin meydana getirmiş olduğu duygusal olgular günümüz toplumlarında kendisine önemli bir yer edinmiş durumdadır (Jones, Reynolds ve Arnold, 2006: 979).

Hedonik tüketim tarzı üzerine yapılmış olan araştırma sonuçlarından da anlaşılacağı üzere bireyler günlük yaşamları içerisinde özellikle tüketim konusundaki seçimlerinde tam anlamıyla mantıksal olarak karar vermemektedirler. Birey satın alacağı ürünün kendisine sağlayacağı duygusal anlamda memnuniyeti yani hazzı daha çok önemsemektedir. Bireylerin duygusal anlamda yaptıkları tüketimlerle hazzı yakalamaları gerektiği konusunda en çok telkinde bulunan araçlar ise kitle iletişim araçlarıdır. Birey günlük yaşam rutini içerisinde kitle iletişim araçlarına maruz kaldığı belki de her dakika hazza yönelik bir tüketim yapması konusunda yönlendirilmektedir. Örneğin, ailesi ve sosyal çevresiyle iletişim kurmak amaçlı telefon satın almak isteyen bir bireyin ihtiyacını karşılayacak ölçüde bir ürünü tercih etmek yerine hayranı olduğu bir televizyon dizisi oyuncusunun kullandığ telefonu satın almayı tercih etmesi onun hazcı bir satın alma tercihi yaptığını göstermektedir.

Özellikle günlük hayatta bireyler satın alma davranışında bulunurken satın almayı tercih ettikleri ürünler kişinin fiziksel ihtiyacını karşılamaya yönelik değil de genellikle kişiyi psikolojik açılardan tatmin etmeyi vaat etmektedir. Kişi anlık olarak satın aldığı ürüne sahip olması durumunda mutluluk yaşasa da bu durum ne yazık ki kalıcı olmamaktadır. Örneğin birey sosyal medyadan takip ettiği maddi durumu kendisinden çok üst seviyede olan bir kişinin giydiği tişörtü satın aldığında kendisini anlık olarak mutlu ve satın aldığı ürün neticesinde tatmin olmuş gibi hissedebilir fakat bu hazc1 duygu kalıcı değildir. Bireyin yaptığı bu duygusal tercihler sebebiyle artık satın alınan ürünlerin kişinin herhangi bir ihtiyacını karşılayıp karşılamadığının bir önemi kalmamakta asıl önemli olan bireye kazandırdığı itibar, imaj yani duygusal anlamda bireyi tatmin edecek bireyi hazza ulaştıracak bir ürün olmasıdır. Bireyin yaptığı bu duygusal ve hedonik seçimlerine yön veren araçlar ise günlük yaşamda bireyin her an muhatap olduğu kitle iletişim araçlarıdır.

Yaşadığımız dönem içerisinde bireyler tüketim tercihlerini duygusal yönde gerçekleştirebildikleri gibi siyasal tercihlerini de kitle iletişim araçlarının yönlendirmesi ile hedonik yönde yapabilmektedirler. Kişi kendisine en çok fayda sağlayacak yani kendisini en çok mutlu edecek siyasal parti hangisiyse o partiye oy verme eğiliminde bulunmaktadır. $\mathrm{Bu}$ süreçte ise bireye fayda sağlayıp onu mutlu edeceğini vaat eden parti üyeleri seslerini kitle iletişim araçları yoluyla hedef kitlelerine duyurmaktadırlar.

Günlük yaşamda bireyler çeşitli siyasal propagandalara ve kamusal mesajlara maruz kalmaktadırlar. Seçmenler artık ülke yönetimini kendi adlarına yapacak siyasi lider ve partileri seçerken akıl odaklı karar vermek yerine siyasilerin kitle iletişim araçlarını kullanarak oluşturdukları algı nedeniyle seçimlerini duygusal yönlü yapmaktadırlar. Örneğin birey yaşadığı toplumda refah, huzur ve ekonomik açıdan bolluk içinde yaşamak ve dolayısıyla Epikuros'un dediği gibi acıdan uzaklaşıp mutlu olmak, hazza yaklaşmak için siyasilerin medya organlarını kullanarak kitlelere ilettikleri mesajlardan etkilenmektedirler ve seçimlerini duygusal yönde kullanmaktadırlar.

\section{Kitle İletişim Araçlarının Günlük Yaşam İçerisindeki Kullanım Alanları ve Hedonizm Odaklı Bireyler}

Medya organları tarafindan bireylere ve makro açıdan bakılacak olursa topluma her gün farklı kanallardan binlerce mesaj iletilmektedir. Ve bu mesajların kitleler üzerindeki etki oranı oldukça yüksektir.

Günümüzde iletişim teknolojilerindeki gelişmeler diğer teknolojik gelişmeleri neredeyse geride bırakmaktadır ve toplumsal açıdan bakıldığında iletişim teknolojilerindeki gelişmeler toplumları çok fazlasıyla etkilemekte ve bununla birlikte kitle iletişim araçları toplumların kültürlerini tanıtma işlevi de görmekte ve aynı zamanda birey kitle iletişim araçlarından toplumu bilgilendirme, eğitme, eğlendirme ve bireyin sosyalleşmesi gibi görevlerini de gerçekleştirmesini beklemektedir (Kocadaş, 2004: 1-2).

Kitle iletişim araçları kullanım sıklığı ve kullanım şeklide bu duruma etki etmekle beraber çok farklı şekillerde bireyi etkiler. Örneğin bir kitle iletişiminin en önemli etkisi bireyin toplumsallaşmasına olan katkısıdır. İlk toplumsallaşma sürecini ailede gerçekleştiren birey kitle iletişim araçlarını kullanmaya başladığı andan itibaren bu iletişim araçlarının etkisine de maruz kalmaktadır.

Kitle iletişim araçları kimi zaman bireyin sahip olmayı çok istediği fakat bir türlü ulaşıp sahip olamadığı yaşadığı toplum içinde kişiyi tatmin edecek bir statü kazandırma imkanını da sağlamaktadırlar. Örneğin bireyleri etkilemek hususunda çok önemli bir kitle iletişim aracı olan televizyonda yayınlanan bir yarışma programı için yapılan bir araştırma bize gösteriyor ki bu yarışmalara en çok başvuran ve yarışma programlarını kendilerini taktir etmek amaciyla kullananların çoğunluğunun belediye lojmanlarında yaşadıkları ve işçi sınıfının üyeleri oldukları keşfedilmiş, bu insanların kendilerine toplumsal yaşamın vermediği bir kişisel statü vermek amaciyla medyayı kullandıkları bu araştırmayla ortaya konulmuştur (Fiske, 2015: 268).

Kitle iletişim araçlarının toplumsal ölçekten bakıldığında farklı etki alanları da mevcuttur. Örneğin toplumda var olan egemen düşüncenin devam ettirilip pekiştirilmesinde ya da bu egemen düşüncenin değiştirilmesinde söz sahibi olabiliyor, bireyleri kendi istekleri doğrultusunda manipüle edebiliyor. 
Aynı zamanda bu iletişim araçları toplumdaki kişilerin kamusal ya da özel alanlarında ne konuşmalarını istiyorlarsa bireyleri bu yönde etkileyebiliyorlar. Yani toplumun gündemini kendi istekleri doğrultusunda belirleyebiliyorlar.

Kitle iletişim araçları bireyler tarafından hangi amaçla kullanılmak istenirse istenilen ve arzu edilen bu amaca hizmet eder. Örneğin eğer tercih edilen kitle iletişim aracı eğitim, bilgi alma ya kișisel gelişime katkı sağlama ve daha çoğaltacağımız birçok sebepten dolayı kullanılırsa kitle iletişim araçlarının bireye olumlu yansımaları olacaktır, aksi bir durumda yani kişinin bu araçları kendi gelişim sürecine hatta yaşam akışına zarar verecek şekliyle kullanırsa o zaman da kitle iletişim araçlarının birey için olumsuz yönleri ortaya çıkacaktır. Yani kitle iletişim araçlarının olumlu yöne ya da olumsuz yöne kullanılması ve bu etkilere maruz kalması kişinin bu araçları hangi amaçla kullandığıyla yakından ilgilidir (Güngör, 2015: 248).

Yukarıdaki paragraflarda açıklanmaya çalışılan kitle iletişim araçlarının statü kazandırma, gündem oluşturma, bilgilendirme, eğitme, eğlendirme gibi işlevlerinden başka bireylerin duyguları üzerinde bir tesir gücü oluşturarak onların hedonizm ekseninde hem ekonomik satın alma süreçlerine hem de siyasal karar verme davranışlarına etkide bulunabilirler. Yani bireyin duyguları onların hem ekonomik satın alma hem de siyasi kararlarına etki edebilir. Hazcı yani hedonizm odaklı satın alma biçimi günümüzde özellikle kitle iletişim araçlarının popüler kültür ürünlerinin tüketilmesi için yaptığı yayınlar sayesinde toplumun neredeyse genelinde gözlemlenebilen genellikle tüketim odaklı olan bir motivasyon biçimidir. Fakat birey hazza ulaşma dürtüsü ile kendisi için faydalı olanı seçme ve seçimlerinin sonucu kendisine mutluluk olarak geri dönüşü olacak tercihler yapmaktadır. Birey bu tutum ve davranışını siyasal anlamdaki seçimlerini yaparken de kullanmaktadır. Daha doğrusu siyasal söylemler bireyin hedonizm odaklı duygularını açığa çıkartmakta ve kişi istenilen doğrultuda hazza ulaşmak, mutlu olmak, bir avantaj elde ederek olan durumdan fayda sağlayarak memnuniyet duymak istemektedir.

Günümüzde siyasal güçler ve sermayeyi elinde bulunduran kişi ya da gruplar günlük yaşam içerisinde kitle iletişim araçlarını kullanarak bireyi kontrol altında tutma çabasındadırlar. Bireyin hem siyasal anlamda hem de tüketim anlamında hedonizm odaklı davranışlarının günlük yaşam içerisinde kitle iletişim araçları kullanılarak nasıl oluşturulduğunu incelemek ve ortaya koymakta fayda olacaktır. Bu açıdan kitle iletişim araçlarının kullanım amaçları bireylerin hedonik karar verme davranışları göz önünde bulundurularak hem siyasal karar verme süreçleri hem de ekonomik satın alma karları çerçevesinde incelenecektir.

Kitle iletişim araçlarının günlük yaşam içerisinde çok çeşitli kullanım amaçları vardır. Bunlardan en çok kullanılan şekilleri aşağıda açıklanmaya çalışılacaktır:

\subsection{Siyasi Propaganda Olarak Kullanılması}

Bireylerin siyasal anlamda ülkeyi yönetenlerin yaptıkları faaliyetleri ve toplum adına aldıkları kararların doğruluğunu kontrol edebilmek ve bu şekilde ülke yönetimine dahil olmaları özellikle yaşadığımız dönemde kitle iletişim araçları yoluyla gerçekleştirilmektedir (Kocadaş, 2004: 131).

İnsan bedeninin uzantısı birer teknolojik aygıt olarak devreye sokulan kitle iletişim araçları modernitenin tesis evrelerinde fetişleştirilmiştir ve insanların iletişim kurmak, çevresinde olup biten olaylar hakkında bilgi almak, haberdar olmak için tasarladıkları medya, kitleler üzerinde ekonomik, siyasal ve sosyo kültürel egemenlik kuran ve aynı zamanda da bu egemenlikleri gerektiğinde yıkabilen efsunlu bir güç haline dönüşmüştür (Anık, 2014: 148-149). Özellikle içinde yaşadığımız zaman dilimine baktığımızda ise kitleler üzerinde önemli bir etkisi olan televizyonun, toplum üzerinde nasıl siyasal bir bask1 ve nasıl siyasal bir propagandanın aracı haline dönüşebildiğini gözlemleyebiliyoruz.

Bu perspektiften değerlendirdiğimizde, günümüzde önemli bir kitle iletişim aracı olan televizyon aracılığıyla izleyiciye aktarılmak niyetinde olunan ileti çok ivedi olarak hedef kitleyle buluşturulabilir (Alp, 2017: 32). Televizyonun sahip olduğu bu özelliğinden dolayı siyasi liderlerin çok sık olarak siyasal propagandalarını yapmak için tercih ettikleri kitle iletişim aracı televizyondur. Hazırlanan bir siyasal kampanya kısa sürede az efor harcayarak kitle iletişim araçları kullanılarak büyük kitlelerle paylaşılabilir. Aynı zamanda siyasi liderin sesi, görüntüsü, jest ve mimikleri televizyon aracılığıyla hedef kitlelerle kolaylıkla buluşturulabilir.

Televizyon seçmene sesini duyurmak ve kendi istekleri doğrultusunda seçmeni yönlendirmek isteyen siyasal aktörlerin en çok kullandığ 1 kitle iletişim aracıdır. Televizyon sesi ve görüntüyü birleştiren ve bunu kitlelere ulaştıran bir kitle iletişim aracı olduğu için siyasal iletişimde sıkça kullanılan bir kitle iletişim aracıdır. Kaynak tarafından hazırlanan siyasi mesajlar seçmene direkt olarak televizyon ya da diğer kitle iletişim araçları kanalıyla iletilir.

Siyasi liderlerin seçmenleriyle yüz yüze bir araya gelmesi çok düşük bir ihtimaldir. Ancak siyasi mitinglerde toplu bir şekilde hedef kitleleriyle bir araya gelirler ve siyasi söylem kullanarak onları etkilemeye çalışırlar. Fakat günümüzde teknolojinin de gelişiminden dolayı kitle iletişim aracının olanaklarından siyasetçilerde faydalanmakta siyasi olarak yapmak istedikleri propagandayı kitle iletişim araçlarını kullanarak yapmaktadırlar. Siyasi propaganda amacıyla en çok kullandıkları kitle iletişim aracı ise televizyondur.

Televizyon siyasi aktörlerin hem sesini hem de görüntüsünü hedef kitlelere hem kolay hem de ucuz bir şekilde ulaştırdığ için seçmene ulaşma anlamında siyasal iletişimde çokça yardımına başvurulmaktadır.

Siyasi söylemler kimi zaman karmaşık ve kitleler tarafindan anlaşılması güç mesajlardır. Siyasi söylemlerin toplumda yaşayan bireyler tarafından da rahatlıkla anlaşıılması için kullanılan en önemli araç kitle iletişim araçlarıdır. Kitle iletişim araçları siyasal söylemleri bireylerin anlayacağı yalın ve anlaşılır bir dille onlara iletir. Bu şekilde yapılan siyasal propaganda daha çok amacına ulaşacaktır. Aksi halde karmaşık siyasal dil büyük kitleler için hiçbir anlam ifade etmeyecek ve siyasal propaganda amacına ulaşamayacaktır.

Bir toplumda iktidar olan siyasal partiler genellikle o ülkenin medya gücünü de elinde bulundurur. İktidar olan siyasal partinin haberleri sıklıkla medyada yer bulur. Fakat bir 
ülkedeki siyasal açıdan iktidarda olmayıp belli bir siyasal seçmene sahip olan partilerinde bu medya organlarında haberlerine yer verilmesi yani muhalefetin haberlerini yapan medya kuruluşlarına da o ülkede yayın yapma hakkı tanınması o ülkedeki siyasal olarak özgür ve nispeten eşit bir siyasal düzene işaret eder.

İktidarı elinde bulunduran siyasal partiler kendi iktidarlarını devam ettirmek için medyayı önemli bir araç olarak kullanırlar. Kitle iletişim araçlarından halka gidecek olan mesajlar önce iktidar tarafindan belirli bir süzgeçten geçirilerek filtrelenir ve daha sonra kitlelere ulaştırılır. Kontrol edilmiş medya içerikleriyle muhatap olan kitleler siyasal iktidarın istediği tutum ve davranışı sergilemeye devam ederler. Yani kitleler üzerinde kitle iletişim araçları vasıtasıyla sağlanan bir kontrol ve denetim mekanizması hakimdir.

Bilgi toplumu çağı, bilginin üretiminin yanında duygunun da üretiminin yapıldığ 1 bir dönemdir, bu sebepten ötürü bireyin kendi hür iradesiyle yönetime katılma hakkı ve kendi seçimlerini kendi istediği gibi yerine getirebilme erki her zaman doğru şekliyle yani işlemesi gerekli olan rutine göre gerçekleşmemektedir, politik özgürlük bireyin kendi seçimlerini gerçekleştirmesi olarak tanımlanamaz, zira bireyin sahip olduğu iradenin oluşum aşamalarını birey tek başına gerçekleştirememektedir (Mattelart ve Mattelart, 2016: 148). Zira bireyi seçim yapma konusunda manipüle eden bir takım ekonomik ve siyasal güçler hakimdir. Bu siyasal ve ekonomik olarak güçlü olan kişi ya da grupların bireyler ve toplumlar üzerinde etkilerini arttırırken ve kişinin özgür iradesini yönlendirmeye çalışırken onlara bu amaçlarında yardımcı olan en büyük güç kitle iletişim araçlarıdır.

Hem sermayeyi elinde bulunduranlar hem de siyasal iktidara sahip olan kişiler medyayı kendi çıkarları doğrultusunda yönlendirmekte ve aynı zamanda medyadaki mesajları önce kendileri denetlemekte ve daha sonra bunu toplumdaki bireylere aktarmaktadırlar. Bu şekilde düzen sağlanmakta bireylerin tutum ve davranışları değiştirilmekte ya da bu tutum ve davranışlar pekiştirilmektedir.

Günümüzde kitle iletişim araçlarının siyasal propaganda amaciyla kullanılması genellikle siyasi liderlerin seçmenlerin manevi duygularına dokunarak gerçekleştirdiği bir süreçtir; çünkü toplum içindeki bireyler seçim günü gelip çattığında hangi partiye oy vereceklerini belirlemeleri gerektiğinde bu duruma rasyonel bir değerlendirme getirmek yerine hisleriyle karar verme yoluna gitmektedirler. İşte tam da burada kitle iletişim araçları devreye girmektedir. Çünkü siyasi liderlerin kendi propagandalarını yaparak halkın gözünde istedikleri gibi manevi bir resim oluşturmayı kitle iletişim araçları yoluyla gerçekleştirmektedirler. Örneğin siyasiler televizyonun ses ve görüntüyü birleştirip hedef kitlelere ulaşma özelliğini bireylerin duygu dünyasını etkileme yönünde çokça kullanmaktadırlar. Günlük yaşam rutini içerisinde seçmenler hangi siyasi liderin kendilerine fayda sağlayıp kendilerini mutlu ederek hazza ulaştıracağına kitle iletişim araçları yoluyla ikna edilirler.

Özellikle seçim dönemlerinde bireylerin ülkeyi yönetecek siyasi liderleri seçme konusunda karar verme süreçlerinde sadece mantıksal olarak hareket ettikleri söylenemez, kişiler siyasi anlamda karar verirken çeşitli psikolojik ve aynı zamanda demografik özelliklerinin etkisi altında kalarak seçimlerini gerçekleştirmektedirler (Fishbein ve Ajzen, 2010: 10)

Yine bireylerin siyasi olarak seçme haklarını kullanacakları sırada yapılan bir araştırmaya göre bireylerin sadece mantıklarıyla değil çeşitli duygu durumlarıyla hareket ettiği gözler önüne serilmiştir. Yapılan bu araştırmaya göre, ülkelerindeki gerçekleşecek olan bir seçim öncesi oy vermek üzere olan bireylerin \%55,4'ü mutluluk ve gurur benzeri çeşitli duygu durumunda olduğu tespit edilmiştir, araştırmaya katılan geri kalan seçmenlerin ise negatif duygu durumu içerisinde olduğu belirlenmiştir (Kurtbaş, 2015: 110). Yapılan bu araştırmaların sonuçları bize açıkça göstermektedir ki bireylerin seçimlerini tek başına mantık oluşturmamakta bireyin duygusal durumu da büyük oranda devreye girmektedir. Kişi mutluluk ve çeşitli fayda beklentisi içinde var olduğu siyasal yapı dahilinde kararını vermektedir. Siyasi güç odakları ise günlük yaşam içerisinde kitle iletişim araçlarını kullanarak bireyi her gün kendilerini desteklemeye devam ederse mutlu ya da huzurlu hissedeceği yönünde telkinlerle yönetmektedirler.

Bireyin seçimleri üzerinde duygularının hâkim olduğu yönünde çalışmaları bulunan Stanfortd Üniversitesi siyasal bilimler profesörü Jon Krosnick ise uzun yıllar boyunca yapılan psikoloji çalışmalarının neredeyse hepsi kişilerin beyinsel fonksiyonlarının iki ana grupta toplandığını ve bireyin günlük yaşamı içerisinde vermiş olduğu kararların birçoğunun farkında olmadan verdiğini belirtmektedir. Krosnick siyasi liderlerin medya organları aracılığıyla seçmenlerle iletişime girdiğinde bireylerin söz konusu liderler hakkındaki kararlarını birçok psikolojik etkenin yönlendirdiğini söylemekte ve bu duruma örnek olarak da ABD'deki 2008 yılında gerçekleştirilen Barrack Obama ve John McCain arasındaki seçmenlik yarışını göstermektedir (www.bbc.com 20.12.2019, https://www.bbc.com/turkce/haberler/2015/05/150528_vert _fut_secmen_tercihi).

Siyasi liderlerin özellikle ülkede yapılacak seçimler öncesinde seçmene verdikleri vaatler genellikle hedef kitlelerin kendilerine oy vermeleri halinde rahatlık ve refah içinde yaşamalarına ve dolayısıyla mutlu huzurlu bir toplumsal ortamda günlük yaşamlarını sürdürecekleri yönünde olmuştur. Örneğin Süleyman Demirel'in 1991 seçimlerinin mitinglerinde "Kim ne veriyorsa beş lira fazlasını vereceğim" cümlesi uzun süre kitle iletişim araçlarında yer almış ve bu vaatlerin sonunda Demirel \%27 oy alarak iktidar olmuştur (www.cnnturk.com Erişim: 20.12.2019,

https://www.cnnturk.com/fotogaleri/yasam/diger/enunutulmaz-secim-vaatleri?page=5). Hedonizmin doğasına uygun olarak yani acıdan kaçınarak hazza ve mutluluğa yaklaşma, birey açısından kendini rahat içinde hissedeceği ortamı sağlayacak siyasi liderin vaatlerine önem vererek o yönde eğilimlerde bulunmasına yol açmaktadır.

\subsection{Kamusal Mesaj Olarak Kullanılması}

Medyanın en önemli vazifesi kamuoyu meydana getirmektir (Şen, 2008: 62). Ülkede olup biten olayları manipüle etmeden toplumla paylaşmak kitle iletişim araçlarının görevleri dahilindedir. Medya sahip olduğu bilgileri tarafsız ve bilginin gerçek ve doğruluğunu kaybetmesine müsaade etmeden kamuoyuna iletmelidir. Aksi halde sahip olunan haberlerin bazı çıkar gruplarının istekleri doğrultusunda 
çarpıtılarak sunulması ve toplum ile paylaşılan bilginin hiçbir değeri olmadığı gibi halkı yanıltıcı ve yanlış bir kamuoyu oluşmasını sağlayıcı bir sonucun ortaya çıkması da çok doğal bir sonuç olacaktır.

Devletlerde var olan siyasal otorite içeriğini kendisinin hazırladığı mesajları topluma aktarırken kitle iletişim aracı en çok baş vurulan iletişim araçlarıdır. Her gün mütemadiyen kitle iletişim araçlarıyla muhatap olan birey siyasi otoritenin onun için hazırladığı mesajı kitle iletişim araçları vasıtasıyla alır. Kitleler bu kamusal mesaj1 aldıktan sonra onlardan beklenen ya siyasal iktidarın istediği bir davranış değişikliğine gidilmesi ya da mevcut davranışın sürdürülüp devam ettirilmesidir.

Siyasal otorite varlığını kamusal mesajların toplum üzerinde bıraktığı etkiye göre sürdürmektedir. Eğer başarılı bir kamusal mesaj hazırlanıp doğru kitle iletişim araçları tercih edilerek bu kamusal mesajlar hedef kitlelere ulaştırılıyorsa gönderilen mesajın beklenilen etkiyi gösterme olasılığı da o denli yüksek olacaktır.

Günümüzde toplumsallaşma üzerinde önemli bir etkiye sahip olan kamusal mesajların siyasal iktidarlar tarafindan hazırlanıp kitle iletişim araçları vasıtasıyla halka ulaştırılması toplumsal fayda gözetilerek yapılması gereken önemli bir süreçtir. Devlet ideolojilerinin kamusal mesajlara yansitılıp bu şekliyle kamuya iletilmesi toplumsallaşma sürecini sekteye uğratıp kamu yararı kavramının gözetilmemesine sebebiyet veren bir durumdur.

Siyasal iktidarlar kendi ideolojik çıkarları doğrultusunda hazırladıkları kamusal mesajları günlük hayat rutini içerisinde halka ulaştırmak yerine kamu yararının gözetildiği halkın toplumsallaşma sürecine olumlu anlamda katkı sağlayacak kamusal mesajlar hazırlayarak ve bu mesajların halka aktarımını sağlayacak en uygun kitle iletişim aracını seçerek toplumda doğru bir kamuoyunun oluşmasına katkı sağlayabilir.

Bireyin siyasal tutumlarını okul çağı döneminden başlayarak, belki de bireyi okul çağı döneminden de daha eski çok küçük yaşlardan itibaren etkisi altına alan ve bu etkisini tüm yaşamı boyunca kaybetmeyen temel bir kamuoyu oluşturma kaynağı da kitle iletişim araçlarının yaptığı yayınlar ve bu yayınların içeriğinde saklı olan mesajlardır (Bektaş, 2000: 92).

Sermayedar grubun ve siyasal iktidarın oluşturdukları kamusal düzenin devam etmesi ya da kendi istek ve beklentileri doğrultusunda değiştirilmesi için bir kamuoyu oluşturmaları zaruri bir gerekliliktir. Toplumda bir kamuoyu oluşturmak için kitle iletişim araçlarına yani medyaya ihtiyaç duyarlar. Bu nedenle kitle iletişim araçlarının günlük hayat içerisindeki bir diğer önemli işlevi bu araçların kamusal mesaj aktarımı için kullanılarak toplumda sermayedarların ve siyasal iktidarların istedikleri gibi bir kamuoyu oluşturmaya çaba sarf etmektir. Zaten sermayedar grubun ve siyasal iktidarın bu sistemde varlıklarını devam ettirebilmeleri söz konusu olan kamuoyunu istedikleri yönde oluşturmalarına bağlıdır. Bunun için de kitle iletişim araçlarına bir nevi muhtaçlardır.

Özellikle kitlesel üretime geçilmesiyle birlikte artık insanların ihtiyacını karşılamak yerine toplum da yaşayan bireylere hiç ihtiyaçları olmadığı halde ürün pazarlanmaya başlanmıştır. $\mathrm{Bu}$ ürünleri toplum içindeki hedef kitlelere pazarlamanın en kolay ve en etkili yolu ise kitle iletişim araçlarını en etkin şekilde kullanmaktan geçiyordu. $\mathrm{Bu}$ nedenle kitle iletişim araçlarından özellikle de çok etkili bir kitle iletişim aracı olan televizyondan izleyicilere pompalanan mesajlar daha çok bireyleri tüketime özendirmeye ve en nihayetinde satın almaya yönlendirmektedir.

Günümüzde kitle iletişim araçlarının bireyler üzerinde sürekli yeni ihtiyaçlar oluşturulmasındaki payı oldukça büyüktür ve dolayısıyla kişiler kendi öz kimliklerini dahi kitle iletişim araçlarından kendilerine iletilen imaj, fabrikalar tarafindan kitleleri tatmin etmek için üretilen tüketim ürünleri ve kitle iletişim araçlarından gönderilen mesajlar doğrultusunda toplumda oluşturulan değerler üzerine inşa ederler (Özgül, 2012: 4528). Yani artık kitle iletişim araçları aracılığıla bireylerde fiziksel ihtiyaçlardan öte duygusal ihtiyaçlar oluşturulmaktadır. Örneğin bireyin yemek yemek için tercih ettiği bir restoran onun için sadece fizyolojik olarak yapılması gereken karnını doyurma eylemini gerçekleştirmek adına mantıksal olarak seçtiği bir yer değil de ona bir statü kazandıran bir mekân haline dönüşür. Yani bireyin bu tercihi onun duygusal olarak da tatmin olmasını sağlayarak hedonik bir tüketim gerçekleştirmesine neden olur.

Hedonik tüketimin ise gerçekleştirilmesine zemin hazırlayan, görüntü ve sesi birleştiren aynı zamanda günlük hayat içerisinde bireyler tarafından sıkça tercih edilen bir kitle iletişim aracı olan televizyon bu özelliğinden dolayı rutin hayat içerisinde kamusal mesajların en iyi aktarıcısı konumundadır. Zira hazırlanan kamusal mesajların toplumla paylaşılması için hangi kitle iletişim aracının yaygınlığı fazlaya o iletişim aracı kullanılmaktadır. Günümüzde ise kullanımı en çok tercih edilen kitle iletişim araçları televizyon ve sosyal medyadır. Sosyal medya teknolojisinin kolay erişime ve özgür iletişime olanak sağlaması kamusal mesajların hedef kitlelere aktarımı ve benimsetilmesi konusunda kolaylık sağlamaktadır. Sosyal medya diğer iletişim teknolojilerine oranla daha özgür ve demokratik bir ortam olarak insanlar tarafindan kullanılıyor ve tercih ediliyor olsa da yine de çeșitli devlet kurumları ve internet sunucuları tarafından çeşitli sansür mekanizmalarına tabi tutulmaktadır. Türkiye'de özellikle sosyal medya platformlarında meydana gelen çeşitli uygunsuz paylaşımlar ve yayınlar Türkiye İletişim Başkanlığı'nın ilgili birimleri tarafindan kontrol edilmekte ve denetlenmektedir.

Kitle iletişim araçlarından özellikle televizyon ve sosyal medya yoluyla bireyle buluşturulan çeşitli içerikler kişide ve dolayısıyla toplumda tek kültürlülük meydana getirmektedir. Örneğin bir toplum içerisindeki birey toplumun genel olarak tükettiği ürünleri satın alıdığı zaman mutlu olmakta ya da kişi genel olarak gençlerin giydiği marka ceketi giydiğinde ya da toplum nezdinde popüler olmuş bir kafenin içeceğini içtiğinde kendisini duygusal olarak tatmin olmuş ve hazza ulaşmış hissedebilir. Ve bu sayede ait olduğu çeșitli sosyal gruplardan da kendisini dışlanmamış hisseder. Bireyin kitle iletişim araçları yoluyla popüler hale getirilen bir ürünü benimsemesi ya da iletişim araçları tarafından karizmatik hale getirilen siyasi bir lidere seçimlerde oy vermesi medya organları tarafindan toplumda meydana getirilen tek kültürlülük durumu ile açıklanabilir.

Kişi toplumdaki hâkim olan bir takım kültürel normların bireye altın tepside ikram ettiği benliği özümser ve bu 
şekilde birey toplumdaki diğer var olan kişiler nasıl ise onlar gibi olur. Dolayısıyla kişi ve kendisinden başka toplumda var olan diğer kişiler arasındaki uyumsuzluk ve toplumdan dışlanarak yalnız kalma, güçsüz olma hissi de yok olmuş olur. Bu şekilde birey kendi kişiliğinden vazgeçmiş olur ve içinde yaşadığı toplum dahilindeki diğer bireylerin aynısı gibi olur. Böylece herhangi bir yalnızlık duygusu edinmez ve bir endişe hali de yaşamaz. Fakat birey bu şekilde kendi benliğinden vazgeçmiş olur (Fromm, 2017: 153).

Formm'un da bahsettiği gibi toplumda var olan kültürel kurallara bireyin sanki kendi benimsediği gerçek normlarmış gibi sarılması ve herhangi bir uyumsuzluk göstermemesi ve bu şeklide kendini daha konforlu ve mutlu hissetmesi yani acıdan uzaklaşıp hazza, mutluluğa yakınlaşması günlük hayatlarında kitle iletişim araçları tarafından kişilere telkin edilmektedir. Çeşitli kamusal mesajlarla bu telkinde bulunan siyasal ve ekonomik güçler ise bireyi bu şekilde kontrolleri altında tutma yoluna gitmektedirler.

İnsanoğlu var olduğu ilk andan günümüze kadar geçen süre içerisinde devamlı olarak rahat edebilme, mutlu ve huzurlu bir hayat sürdürme, acıdan uzaklaşma ve hazza ulaşma gibi duyguları yaşamış ve yaşamaya devam etmektedir. Bu nedenledir ki toplumsal düzen içerisinde kendini ne mutlu hissettirecekse o olguya doğru yönelmiştir. Günümüzde ise özellikle tüketim kültürünün bireylere ve kitlelere dayattığı tüketme ve bu tüketim sonucunda mutluluğa ulaşacağına dair telkinler günlük hayat içerisinde bireye kitle iletişim araçları vasıtasıyla kamusal mesaj olarak iletilmektedir. Her gün tüketimin cazibesine kitle iletişim araçlarıyla ikna edilen birey tüketme odaklı olarak hayatını devam ettirmektedir. Kendisine tükettikçe mutlu olacağı telkin edilen birey anlık mutluluklar yaşasa da gerçek mutluluğu aslında yakalayamamaktadır.

\subsection{Kontrol Amacı ile Kullanılması}

Kitle iletişim araçlarının patronları ya da ülkede iktidar olan siyasi liderler veya ülkede hâkim olan ekonomik liderler medyayı kullanarak kamuoyu oluşturmaya çalışırlar. Kitle iletişim araçlarında var olan programların içeriklerine istedikleri gibi müdahale edebilen bu güçler, toplumu istedikleri yönde etkileyebilmektedirler. $\mathrm{Bu}$ anlamda kitleleri kontrol altında tutmak için kitle iletişim araçları onlar için muazzam bir hazinedir.

İletişim teknolojilerindeki gelişim ve değişime bağlı olarak medya yoluyla toplumda çok büyük sayıdaki insan topluluklarına ulaşılabilir hale gelinmiştir. Kitle iletişim araçları kullanılarak ulaşılan insan sayısına çok yakın zamana kadar başka bir teknolojinin ulaşması pek de mümkün görülmüyordu. İşte bu durum kitle iletişim araçlarının sahip olduğu yükümlülükleri artırırken bu iletişim araçları toplumda var olan değerleri yok sayıp tamamen farklı istediği gibi, gerçek olmayan yapay bir dünyada meydana getirebilir ya da toplumda var olan ahlaki yapıya tamamen ters düşen içerikte programlarda hazırlayıp topluma sunabilir; fakat bununla birlikte varlığını sürdürdüğü toplum içinde var olan bir takım önemli değer yargıları ve o toplumda çok önemli sayılan toplumu oluşturan ana parçaları önemseyen programlar da hazırlayıp doğru bir şekilde işleyen bir yapıya sahip bir toplum meydana getirebilir (Ceylan, 2012: 45).
20. yüzyılın en dikkat çekici ve kültürleri, toplumları kolayca etkisi altına alabilen teknolojik gelişmelerinden birisi olan kitle iletişimi, çağa adını verecek kadar günümüzde önem kazanmıştır ve sosyal, siyasal, ekonomik alanda birçok alanı etki altına almakla beraber, hatta günümüzde kitle iletişim araçları toplumsal, siyasal ve ekonomik gelişmenin, değişmenin ön koşulu olarak bile görülmektedir (Anık, 2016: 75).

Medya organları her ne kadar siyasal iktidarın ya da o ülkedeki ekonomik gücü elinde bulunduranların mesajlarını halka iletse de kitle iletişim araçları toplum üzerinde hakimiyet kurmak isteyen bu grupların kontrol altında tutulmasını sağlar. Bu kontrol mekanizması ise iktidarın ya da gücü elinde bulunduran kişilerin kitle iletişim araçları ile eleştirilmesidir. Yapılan bu eleştiri sayesinde gücü elinde bulunduran kesim her zaman temkinli davranmaktadır. Aksi halde kontrol mekanizmasının devreye gireceğini bilirler.

Fakat yukarıda anlattığımız durumun tam tersi bir durumunda gerçekleşmesi olasıdır. Kitle iletişim araçları toplumu kontrol altında tutma amacıyla da kullanılabilir. Hedef kitleleri kontrol altında tutmak amacıyla medyadaki haber içerikleri değiştirilebilir. Kitleler medya aracılığıyla maniple edilerek hem siyasal hem de ekonomik anlamda iktidarlar tarafından istenilen davranış şekline yönlendirilebilir. Ya da iktidarlar düzenin durağan kalıp devam ettirilmesini de isteyebilir. Bu durumda mevcut duruma uygun bir içerik hazırlanarak kitle iletişim araçları vasıtasıyla kitlelere ulaştırılır. Ve böylece iktidarlar tarafından kitle iletişim araçları toplumu kontrol altında tutmak amacıyla kullanılmış olur.

Günümüzde yukarıda bahsettiğimiz durumun örneklerini günlük hayat içerisinde sıkça yaşamaktayız. Fakat kitle iletişim araçları kullanarak halkı kontrol altında tutmak yerine bu iletişim araçları kullanılarak halk mevcut siyasi ve ekonomik sistem hakkında bilgilendirilebilir, toplumsallaşmanın sağlıklı gerçekleşmesi için medya yoluyla halkın eğitilmesi sağlanabilir.

İktidarın kontrolü altında bazı dönemlerde toplumda eleştirilerin de yapılmasına izin verilebilir. $\mathrm{Bu}$ eleştiriler sayesinde iktidara karşı toplumda bir rahatlama yaşanır ve kitlelerin mevcut düzene rıza göstermesi sağlanır. Bu durum özellikle ülkedeki seçim döneminde sıkça başvurulan bir yöntemdir.

Geniş kitleler siyasal ve ekonomik çıkar grupları tarafından kontrol altında tutulmak istendiği için duygusal anlamda kendi çıkarları yönünde ikna edilmeye çalışılırlar. Bu duruma siyasal olarak kitlelerin kontrol altında nasıl tutulmaya çalışıldığını açıklamaya çalışarak başlayabiliriz. Örneğin seçim propagandalarında halihazırda iktidarda olan parti ülke ekonomisinin istikrarlı bir şekilde yoluna devam etmesi için kendilerinin siyasi liderliklerinin devam etmesi gerektiğini çeşitli siyasal iletişim teknikleriyle seçmene iletirler. Kitlelerin ancak bu şekilde mutlu, huzurlu ve kaygıdan uzak kalacağı mesajını onlara verirler ve seçmenlerin hedonist duygularla karar vermelerini sağlayarak bireyleri kitle iletişim araçları yardımıyla gönderdikleri mesajlarla kontrol altında tutmaya gayret gösterirler.

24 Haziran 2018 seçimleri öncesi bazı siyasi partilerin kitle iletişim araçları yoluyla seçmenleriyle paylaştıkları sloganlar aşağıdaki gibidir: 
- $\quad$ AKP: Güçlü Meclis, Güçlü Hükümet, Güçlü Türkiye: Yaparsa Yine Ak Parti Yapar

- $\quad$ Millet karar verecek istikrar devam edecek

- $\quad$ Birlik, bereket, bolluk için vakit Türkiye vakti (www.hurriyet.com.tr $\quad$ Erişim: 01.01.2020, http://www.hurriyet.com.tr/galeri-iste-ak-partinin-secimkampanyasinda-kullanacagi-sloganlar-40845707/2).

2019 yerel seçimleri için hazırlanan CHP’nin kullanmış olduğu sloganlar ise;

\section{- Derman Belediyeciliği}

- Martın sonu bahar (www.hurriyet.com.tr Erişim: 21.12.2019, http://www.hurriyet.com.tr/gundem/chpgorsel-iletisim-kilavuzu-yayinladi-41064728).

Yukarıda paylaşılan seçim sloganları seçmene benzer vaatlerde bulunmaktadır; siyasi partilerin hepsi bireyin kendilerini seçmesi durumunda huzurlu, mutlu acıdan uzak bir yaşama ulaşacaklarını vaat eden ve seçmeni hedonist yani duygusal yönden etkilemeye çalışan mesajlar paylaşmaktadırlar. Siyasi liderler tarafından hedef kitlelerle paylaşılan çeşitli vaatler ve sloganlar ise kitleleri kontrol altında tutma yöntemlerinden sadece bir tanesidir. Bu tür mesajlara birey sadece seçim dönemlerinde değil günlük yaşam seyri içerisinde özellikle bilgi alma ihtiyacını yerine getirmek için okuduğu haber içerikli yazılarda ya da izlediği programlarda her gün maruz kalmaktadır.

Siyasi liderlerin kitle iletişim teknolojilerini kullanarak hedef kitleleri kontrol altında tutma stratejileri günümüzde ekonomik olarak toplumda hakimiyet kuran kişi ya da kurumlar tarafından da uygulanan bir yöntemdir. Bu anlamda bireylerin ve toplumun kontrol altında tutulması yönündeki eylemler kitle iletişim teknolojilerindeki gelişim ile beraber medya organlarının günlük yaşam koşuşturması içerisinde her türlü gruba, topluma, bireylere kolayca ulaşılabilmesiyle daha da etkili hale gelmiştir. Kitle iletişim araçlarının ise kitleler üzerinde oluşturduğu en önemli etki, toplum içinde popüler bir kültür meydana getirip kitleleri tüketime ve eğlenceye yönlendirerek kontrol altında tutmaya çalışmaktır.

Ülkedeki var olan ekonomik güç odakları yine kitle iletişim araçlarını kullanarak kitleleri duygusal anlamda hedonizm çerçevesinde her gün gönderdiği mesajlarla kontrol altında tutmaya çalışır ve bu amaçla duygusal reklamlar çok fazla üretilir. Artık günümüzde aslında gerçek bir ihtiyaç olmayan fakat tüketim kültürü tarafından ortaya çıkarılmış olan sahte gereksinimler, istek ve arzular, çoğu zaman gerçek gereksinimlerin bile önüne geçebilmektedirler (Akkaş, 2019: 21). $\mathrm{Bu}$ anlamda markalar insanlara sadece ürün değil bir yaşam tarzı da pazarlarlar. $\mathrm{Bu}$ ürünleri satın alan birey kendisini duygusal olarak tatmin olmuş hisseder.

Özellikle televizyon dizilerindeki ünlü karakterlerin kullandıkları ürünler çeşitli pazarlama faaliyetleri kullanılarak çok fazla göz önüne çıkartılır. Birey sevdiği ve kitle iletişim araçlarında görüp izlediği severek takip ettiği bu kişi gibi olmak için onun kullandığı ürünleri satın alarak bu şekilde kendini tamamlanmış hisseder ve mutlu olur.

\section{Sonuç}

20. yüzyıldan itibaren kitle iletişim teknolojilerinde meydana gelen gelişmeler medyanın kitleler üzerindeki etkisini tahmin edilemez boyutlara taşımıştır. Günümüzde günlük yaşam içerisinde bireyler kitle iletişim araçlarından gelen iletilerle çepeçevre sarılmış durumdadır. Özellikle günümüzde iletişim teknolojilerinde yaşanan değişim ve gelişim sayesinde kitle iletişim araçlarının toplum üzerindeki hakimiyet gücü daha da artmıştır. Günlük yaşam koşuşturması içinde çeşitli nedenlerle kitle iletişim araçlarını kullanan bireyler bu iletişim araçlarının çoğu zaman olumsuz etkilerine maruz kalmaktadırlar. Ekonomik ve siyasal gücü elinde bulunduran gruplar kendi çıkarları doğrultusunda teknolojik gelişmelerin de yardımıyla kitle iletişim araçlarını kullanarak toplumdaki hakimiyet derecelerini her geçen gün daha da arttırmaktadırlar.

İnsanlık tarihi boyunca birey tercihlerini gerçekleştirirken kendini nasıl daha mutlu hissedeceğini ve yaşamını daha huzurlu bir şekilde nasıl yaşayacağını bulma arayışı içerisinde olmuştur. Geleneksel toplum yapısı içerisinde bireyler genellikle üretme odaklı yaşarken günümüzde bireyler daha çok tüketim kültürünün birer işçisi konumundadırlar. $\mathrm{Bu}$ çerçeveden bakıldığında birey hem siyasal tercihlerinde hem de ekonomik tercihlerinde kendisini duygusal anlamda tatmin edecek yani hedonizm ekseninde değerlendirecek olursak acıdan uzaklaşıp kendisini huzura ve mutluluğa ulaştıracak olguların arayışı içerisinde olmuştur. Toplum içerisinde var olan ekonomik ve siyasal gruplar ise bireyin bu duygusal arayışından faydalanarak onun günlük yaşamı içerisindeki tercihlerini kitle iletişim araçlarını kullanarak etkilemeye çalışmışlardır. $\mathrm{Bu}$ açıdan bakıldığında bahsi geçen çıkar gurupları her ne kadar bireyin mutlu olması adına çaba sarf ediyormuş gibi görünse de aslında yaptıkları kendi çıkarları doğrultusunda kitle iletişim araçları yoluyla siyasal propaganda yapmak, kamusal mesajlar vererek bireyi kontrol altında tutmak ve yönlendirmek, bireylerin ekonomik satın alma süreçlerini kendi çıkarları doğrultusunda etkilemekten ibaret olmuştur.

\section{Kaynakça}

Akkaş, İbrahim. (2019). İzlenim Yönetimi ve Beden. Konya: Eğitim Yayınevi

Anık, C. (2014). İletişim Sosyolojisi Kuramsal Temeller. İstanbul: Der Kitapevi Yayınevi

Anık, C. (2016). Siyasal İkna. İstanbul: Der Kitapevi Yayınevi.

Anıl, B., \& Köksal, E. (2016). Türkiye'de İnterneti Kimler, Ne İçin Kullanıyor?. Marmara Üniversitesi İktisadi ve İdari Bilimler Dergisi, 38(1), 1 - 13.

Aziz, A. (2013). Televizyon ve Radyo Yayıncılığı (Giriş). İstanbul: Hiperlink Yayınları.

Aziz, A. (2016). İletişime Giriş. İstanbul: Hiperlink Yayınları.

Bektaş, A. (2000). Kamuoyu, İletişim ve Demokrasi. İstanbul: Bağlam Yayınları. 
Biagi, S. (2007). Media/Impact: An Introduction to Mass Media. United States of America: Thomson Wadsworth.

Ceylan, Y. (2012). Toplumsal Değerler ve Medya Etiği. Dicle Üniversitesi Sosyal Bilimler Enstitüsü Dergisi, 4(7), 45-58.

Çakır, H., \& Topçu, H. (2005). Bir iletişim Dili Olarak İnternet. Erciyes Üniversitesi Sosyal Bilimler Enstitüsü Dergisi, 1(19), 71-96.

Erdem, H. H. (2014). Kitle İletişimi, Etik ve Eğitim. Gazi Üniversitesi Gazi Eğitim Fakültesi Dergisi, 1(3), 63 77.

Fishbein, M., \& Ajzen, I. (2010). Predicting And Changing Behavior. New York: Psychology Press Taylor \& Francis Group.

Fiske, J. (2011). İletişim Çalışmalarına Giriş. S. Çiftçi ve Ü. H. Yolsal (Çev.). Ankara: Pharmakon Yayınevi.

Fromm, E. (1996). Özgürlükten Kaçış. Şemsa Yeğin (Çev.). İstanbul: Payel Yayınevi

Güngör, N. (2015). İletişime Giriş. Ankara: Siyasal Kitabevi.

Hilmes, M., \& Loviglio, J. (Ed.). (2002). Radio reader: Essays in The Cultural History of Radio. New York: Routledge.

Hirschman, E. C., \& Holbrook, M. B. (1982). Hedonic Consumption: Emerging Concepts, Methods and Propositions. Journal of Marketing, 46(3), 92-101.

Işık, M. (2012). Kitle İletişim Teorilerine Giriş. Konya: Eğitim Kitapevi Yayınları.

Işık, Metin. (Ed.). (2019). İletişim ve Etik. Konya: Eğitim Yayınevi

Jones, M. A., Reynolds, K. E., \& Arnold, M. J. (2006). Hedonic and Utilitarian Shopping Value: Investigating Differential Effects on Retail Outcomes. Journal of Business Research, 59(9), 974981.

Kaya Deniz, A. (2019). Dijital Çağın Hedonist Çalışanları: Dijital Göçebeler. IBAD Sosyal Bilimler Dergisi, 5, 101-113.

Kaypakoğlu, S. (2004). Küresel Medya ve Kültürel Değişim. İstanbul: Naos Yayıncılık.

Kocadaş, B. (2004). Kültür ve Medya. İnsan Bilimleri Dergisi, 1(1), 1-8.

Kurtbaş, İ. (2015). Seçmen Psikolojisine Dair Psiko-Politik Bir Tahlil "Politik Psikloji Ekseninde Deneysel Bir Çalışma”. Journal of Administrative Sciences and Policy Studies, 3(2), $91-11$.

Mattelart, A. (2016). İletişimin Dünyasallaşması. Halime Yücel (Çev). İstanbul: İletişim Yayınları.

Mattelart, A. ve M. Mattelart (2016). İletişim Kuramları Tarihi. Merih Zıllıŏlu (Çev.). İstanbul: İletişim Yayınları.

Özgül, G. (2012). Bir Görme Biçimi Olarak Yeni Medya: Kamusal Bir Alan İmkanının Araştırılması. Journal of Yaşar University, 7(26), 4526-4547.
Öztürk Fidan, İnci. (2017). Hedonizmden Püritanizme: Eğitim Felsefesine İlişkin Bir Değerlendirme. Anemon Muş Alparslan Üniversitesi Sosyal Bilimler Dergisi, 5(3), 579 - 621.

Postman, N. (2014). Televizyon: Öldüren Eğlence. Osman Akınhay (Çev.). İstanbul: Ayrıntı Yayımları.

Sorlin, P. (1997). Mass Media. Second Edition. London: Routledge.

TDK. (2006). Güncel Türkçe Sözlük. (Erişim: 11.02.2019), www.tdk.gov.tr

Turan, S., \& Esenoğlu, C. (2006). Bir Meşrulaştırma Aracı Olarak Bilişim ve Kitle İletişim Teknolojileri: Eleştirel Bir Bakış. Eskişehir Osmangazi Üniversitesi İİB Dergisi, 1(2), 71-86.

Van Dijck, J. (2013). The Culture of Connectivity: A Critical History of Social Media. New York: Oxford University Press.

Walker, N. A. (1998). Women's Magazines, 1940-1960: Gender Roles and the Popular Press. Boston: Palgrave Macmillan

Williams, K. (2010). Read All about İt! A History of the British Newspaper. New York: Routledge.

Williams, R. (2004). Television: Technology and Cultural Form. New York and London: Routledge.

Yaylagül, L. (2016). Kitle İletişim Kuramları. Ankara: Dipnot Yayınları.

Zillığlu, M. (2014). İletişim Nedir?. İstanbul: Cem Yayınevi.

(Erişim: 01.01.2020), http://www.hurriyet.com.tr/galeriiste-ak-partinin-secim-kampanyasinda-kullanacagisloganlar-40845707/2

(Erişim:

20.12.2019) https://www.bbc.com/turkce/haberler/2015/05/1505 28_vert_fut_secmen_tercihi

(Erişim: 20.12.2019), https://www.cnnturk.com/fotogaleri/yasam/diger/enunutulmaz-secim-vaatleri?page $=5$

(Erişim:

21.12.2019), http://www.hurriyet.com.tr/gundem/chp-gorseliletisim-kilavuzu-yayinladi-41064728 